\title{
Nine-year results on maize and processing tomato cultivation in an organic and in a conventional low input cropping system
}

\author{
Michela Farneselli, Paolo Benincasa, Giacomo Tosti, Roberta Pace, Francesco Tei, \\ Marcello Guiducci
}

Dipartimento di Scienze Agrarie ed Ambientali, Università di Perugia, Italy

\begin{abstract}
Nine-year results on yields and apparent balances of organic matter and nitrogen $(\mathrm{N})$ are reported for maize and processing tomato cultivated in a long term comparison trial between an organic and a conventional low-input system in Central Italy. In every year, above ground biomass and $\mathrm{N}$ accumulation of each cash crop and green manure, including weeds, and the partitioning between marketable yield and crop residues were determined. Apparent dry matter and nitrogen balances were calculated at the end of each crop cycle by taking into account the amounts of dry matter and ex-novo $\mathrm{N}$ supplied to the system as green manure legume $\mathrm{Ndfa}$ (i.e. an estimate of $\mathrm{N}$ derived from the atmosphere via symbiotic fixation) and fertilizers, and those removed with marketable yield. Processing tomato complied with organic cultivation better than maize. As compared to the conventional crop cultivation, organic tomato provided similar yields, used supplied $\mathrm{N}$ more efficiently and left lower residual $\mathrm{N}$ after harvest, with lower related risks of pollution. Organic maize yielded less than conventional one. The main limitation for organic maize was the low $\mathrm{N}$ availability during initial growth phases, due to either low $\mathrm{N}$ supply or low rate of $\mathrm{N}$ release from incorporated green manure biomass. In both organic and conventional cultivation the system sustainability could be improved by an appropriate crop rotation: wheat in fall winter likely prevented leaching loss of mineral $\mathrm{N}$ in both systems; green manure crops in the organic system allowed to either trap and recycle soil mineral $\mathrm{N}$ or supply ex novo legume Ndfa to the soil, with benefits in mitigation of $\mathrm{N}$ pollution and improvement in self-sufficiency of the system.
\end{abstract}

Correspondence: Paolo Benincasa, Dipartimento di Scienze Agrarie ed Ambientali, Università di Perugia, Borgo XX Giugno 74, 06121 Perugia, Italy. Fax: +39.755 .856344 .

E-mail: paoloben@unipg.it

Key words: biomass, yield, nitrogen, green manure, residue, apparent balance.

Conference presentation: SIA Congress, Teramo 2011.

Received for publication: 26 October 2012.

Revision received: 13 December 2012.

Accepted for publication: 15 December 2012.

(C) Copyright M. Farneselli et al., 2013

Licensee PAGEPress, Italy

Italian Journal of Agronomy 2013; 8:e2

doi:10.4081/ija.2013.e2

This article is distributed under the terms of the Creative Commons Attribution Noncommercial License (by-nc 3.0) which permits any noncommercial use, distribution, and reproduction in any medium, provided the original author(s) and source are credited.

\section{Introduction}

The effects and implications of organic and conventional cropping systems on crops and the environment can be accurately evaluated only in the long term period, on the basis of poli-annual results from comparative field crops trials appropriately conceived for this aim (Fließbach et al., 2006; Boldrini et al., 2008; Thorup-Kristensen et al., 2012). The main bottle-necks of organic systems are represented by the management of soil fertility (Watson et al., 2002) and the control of weeds (Graziani et al., 2012), pests and diseases (Ferron and Deguine, 2005), all affecting crop yield. With respect to the management of soil fertility for spring-summer cash crops, several researches demonstrated that nitrogen $(\mathrm{N})$ can be efficaciously supplied by means of fertility building crops, thanks to either recycling of soil mineral $\mathrm{N}$ or legume $\mathrm{N}$ fixation (Thorup-Kristensen et al., 2003; ThorupKristensen and Dresbøll, 2010; Thorup-Kristensen et al., 2012). However, not all cash crops comply the same way with organic management (de Ponti et al., 2012).

A long term experiment for the comparison between an organic system and a conventional low input system was carried out in Central Italy (Boldrini et al., 2007, 2008). Authors focused on dynamics and balances of organic matter and nutrients in the soil for each system as a whole, while no data have been reported in detail until now for single crops. In that experiment, maize and processing tomato have been present as spring summer cash crops since 2002. These two crops differ much for $\mathrm{N}$ uptake capacity (also due to different plant spacing), total amount and timing of $\mathrm{N}$ need, effect of $\mathrm{N}$ on crop yield (also due to different requirements for marketable yield between a cereal and a vegetable). Maize is a high $\mathrm{N}$ demanding crop with early spring sowing and green manures may not guarantee an adequate $\mathrm{N}$ availability especially in early growth phases, with consequent lower growth and grain yield (Benincasa et al., 2008, 2010; Teasdale et al., 2008). Processing tomato may better use organic $\mathrm{N}$ sources in virtue of its lower and later $\mathrm{N}$ need due to its mid spring transplanting date (Tosti et al., 2008). Also the $\mathrm{N}$ leaching risk for the two crops may be differently affected by fertilization strategies in organic and conventional systems. However, the use of green manures has been demonstrated to reduce the risk of nitrate leaching for both maize (Salmeron et al., 2010; Gabriel et al., 2012) and processing tomato (Farneselli et al., 2009), provided a non legume species is present as pure stand or intercropped with legumes.

Recently, Tosti et al. (2012) have reported a comparative study on N nutrition of maize and processing tomato fertilized by using green manures. That 2-year experiment however was not focused on the effect of farming systems and actually maize and tomato had been grown on fields all having conventional management history. One might object that the two crops might have different performances if cultivated in a soil with an organic management history where cumulative effects of the organic management on soil properties may come out. Moreover, due to year-by-year variability in climatic conditions 
and biotic disease during both green manures and cash crops, to be accurate, the study of a crop in a certain cropping system should consider many years.

For this reason, the aim of this work was to compare the nine-year results on yields and apparent balances of organic matter and nitrogen for maize and processing tomato cultivated in a long term comparison trial between an organic and a conventional low-input system in Central Italy.

\section{Materials and methods}

The field experiment was located at our Experimental Station in Papiano (Central Italy, $15 \mathrm{~km}$ south from Perugia, middle Tiber valley, $43^{\circ} \mathrm{N}, 12.3^{\circ} \mathrm{E}, 165 \mathrm{~m}$ asl). Maize and processing tomato crops have been cultivated between 2002 and 2010 in an organic system (ORG) and in a conventional low-input system (LOW). The two cropping systems were carried out since 1999 on two contiguous fields, originally homogeneous for soil properties [clay loam, with same initial contents of soil organic matter, total N, available phosphorus (P) and exchangeable potassium (K)]. In 1996, as required by the EU 2092/91 regulation, the ORG field underwent to the transition from conventional to organic. During this transitional period (1996-1998), this field was cropped with alfalfa (Medicago sativa $\mathrm{L}$.), while the other field (LOW) was subjected to a very common crop sequence in central Italy (faba bean, silage maize, faba bean). Therefore, such a transitional period should be regarded as an integral part of the experimental lay-out.

From 1999 onwards, same rotations were set-up in the two fields and good ordinary management practices were always selected, in strict adherence to EU regulations for organic and conventional low-input farming systems (ORG: EU reg. 2092/91; LOW: EU reg. 2078/92). Starting from 2002, these rotations became more regular and characterized by the same basic sequence of cash crops over a 6 -year period: summer cereal (maize) - industrial vegetable (processing tomato) winter cereal (durum wheat) - grain legume (in most cases faba bean or common pea) - summer vegetable (in most cases melon or sweet pepper) - winter cereal (soft wheat). In order to reproduce the steadystate running of the basic 6-year rotation in a farm and test all the six crops of the sequence in each year, six different orderings were realized for both ORG and LOW field, each ordering starting with a different crop of the sequence. The six orderings were laid down on a completely randomized design with three replicates and plot sizes of 120 $\mathrm{m}^{2}$. The main differences between the two systems concerned $\mathrm{N}$ fertilization management and crop protection. The $\mathrm{N}$ fertilization in ORG was carried out by fall-winter green manures (in most cases pure faba bean before maize, and hairy vetch+barley intercrop before processing tomato) integrated in case by organic fertilizers, while in LOW chemical fertilizers were used. Weed control was mechanical in ORG, integrated (chemical+mechanical) in LOW. Pest and disease control in ORG used allowed products, in LOW conventional chemicals. Other agronomic practices (variety selection, implant dates, plant arrangement, water management) were the same in both systems. Optimal implant dates were always adopted for each crop (beginning of November for wheat, field bean, pea and green manure intercrops; mid April for maize; mid May for transplanted vegetables (i.e. processing tomato, melon and sweet pepper). In agreement with a low input management for both systems, maize received a reduced water supply of $100 \mathrm{~mm}$ per year split in two irrigations. On the other hand, the irrigation of processing tomato fully satisfied crop water requirements with a total of $350 \mathrm{~mm}$ per year and a twice-a-week irrigation schedule. Further details on the whole experimental design for the comparison between the organic and the conventional low-input systems are reported by Graziani et al. (2012).

In every year, above ground biomass and $\mathrm{N}$ accumulation of cash crops and green manures, including weeds, and the partitioning between marketable yield and crop residues were determined by plant samplings and analysis of organic $\mathrm{N}$ concentration in the dry matter (Kjeldhal method). In particular, at harvest time, sixteen plants per plot were sampled for processing tomato and all plants from four 10-meterlong core rows per plot were sampled for maize. Biomass partitioning was then determined on sub-samples. Apparent dry matter and $\mathrm{N}$ balances were calculated at the end of each crop cycle according to the following equations:

$$
\Delta \mathrm{M}=\mathrm{DM}_{\mathrm{GM}}+\mathrm{DM}_{\mathrm{OF}}+\mathrm{DM}_{\mathrm{CC}}-\mathrm{DM}_{\mathrm{MY}}
$$

where

$\Delta \mathrm{M}=$ apparent variation of dry matter in the system

$\mathrm{DM}_{\mathrm{GM}}=$ above ground dry matter from green manures (including weeds)

$\mathrm{DM}_{\mathrm{OF}}=$ dry matter from organic fertilizers

$\mathrm{DM}_{\mathrm{CC}}=$ above ground dry matter from the cash crop (including weeds)

$\mathrm{DM}_{\mathrm{MY}}=$ dry matter removed from the field with marketable yield

$$
\Delta \mathrm{N}=\mathrm{Ndfa}_{\mathrm{GM}}+\mathrm{N}_{\mathrm{F}}-\mathrm{N}_{\mathrm{MY}}
$$

where

$\Delta \mathrm{N}=$ apparent variation of $\mathrm{N}$ in the system (i.e. residual $\mathrm{N}$ in the soil) $\mathrm{Ndfa}_{\mathrm{GM}}=$ above ground $\mathrm{N}$ derived from atmosphere accumulated by green manure legumes

$\mathrm{N}_{\mathrm{F}}=$ fertilizer- $\mathrm{N}$

$\mathrm{N}_{\mathrm{MY}}=\mathrm{N}$ removed from the field with marketable yield

Therefore, the actual ex novo $\mathrm{N}$ supplied to the system was calculated by taking into account, besides fertilizer $\mathrm{N}$, only the amount of above-ground green manure $\mathrm{N}$ derived from the atmosphere (Ndfa). This, in our environment, was estimated to account for $80 \%$ of total above ground legume $\mathrm{N}$ for faba bean and hairy vetch, according to Boldrini et al. (2007). The remaining 20\% was thus assumed to be absorbed from the soil and not considered in the balance because already present in the system. The dry biomass and $\mathrm{N}$ accumulated in roots was not taken into account for apparent balances.

\section{Results}

The marketable yield of both crops varied across years (Figure 1). In maize it was generally lower in ORG than in LOW (-22\%, on average over all years), while in processing tomato it was not much different between systems (-2\%, on average over all years) except for the last two years when controversial evidences were observed (ORG/LOW ratio=1.47 in 2009 and 0.52 in 2010).

Figure 2 shows the biomass supplied to the system, calculated by difference between total above ground biomass (i.e. that from cash crop and weeds and, in addition for ORG, that from green manure and organic fertilizers) and marketable yield. The ORG management increased biomass supply to the soil, especially in processing tomato where difference from LOW was always positive across years ranging between $+65 \%$ and $+140 \%$.

The actual $\mathrm{N}$ supply (i.e. fertilizer $\mathrm{N}$ plus green manure legume Ndfa) for both crops was generally lower in ORG than in LOW (-20\% in maize and $-29 \%$ in processing tomato, on average over all years) (Figure 3). Moreover, differently from the well defined mineral $\mathrm{N}$ supply in LOW, important yearly variation were recorded for the actual $\mathrm{N}$ 
supply in ORG. The $\mathrm{N}$ use efficiency (NUE) of each crop is intended here as the ratio between the marketable yield dry matter and the actual $\mathrm{N}$ supply to the crop (Figure 4). The NUE varied year by year in both crops with wider variations in ORG. The effect of systems on maize NUE was not univocal and substantially risible (-2\% in ORG, on average over all years), while the NUE of processing tomato was generally higher in ORG than in LOW $(+49 \%$, on average over all years, $+28 \%$ excluding the exceptional $+222 \%$ of 2009 ).

The residual $\mathrm{N}$ in the soil after harvest (i.e. the actual $\mathrm{N}$ supply minus the $\mathrm{N}$ removed from the soil with marketable yield) varied year by year in both systems and crops (Figure 5). On average over all years it did not differ much in maize ( $33 \mathrm{~kg}$ in ORG $v s 37 \mathrm{~kg}$ in LOW) while it was much lower for ORG than for LOW in processing tomato (18 vs $47 \mathrm{~kg}$, respectively).
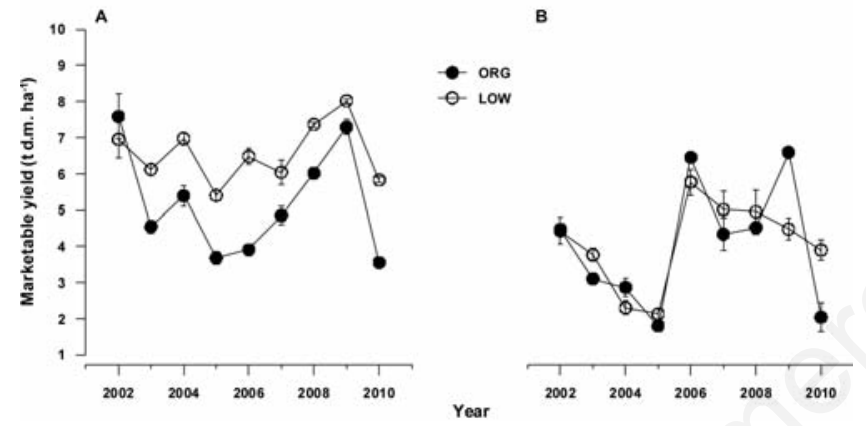

Figure 1. Marketable yield ( $\mathrm{ha}^{-1}$ of d.m.) for A) maize and B) processing tomato in the organic ( $O R G=$ full circles) and the conventional low input (LOW=empty circles) system across years 2002-2010. Vertical bars represent \pm 1 SE of the mean.
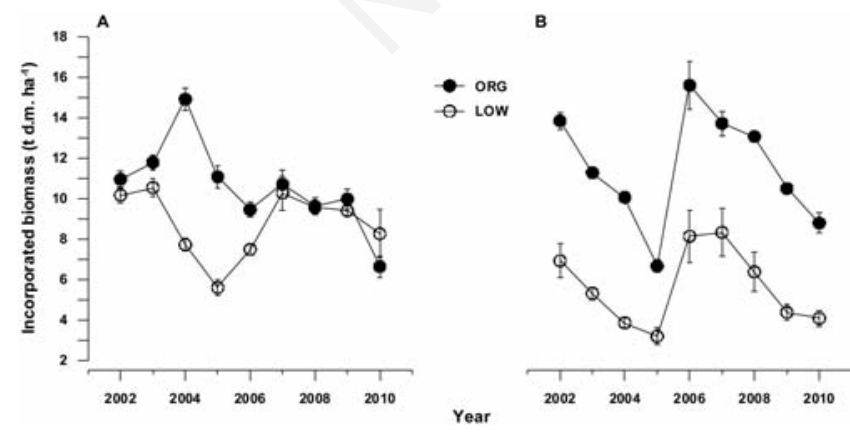

Figure 2. Amount of biomass ( $\mathrm{ha}^{-1}$ of d.m.) incorporated into the soil (i.e. total above ground biomass of each crop included weeds minus marketable biomass plus green manure biomass and organic fertilizer biomass) for A) maize and B) processing tomato in the organic (ORG=full circles) and the conventional low input (LOW=empty circles) system across years 2002-2010. Vertical bars represent $\pm 1 \mathrm{SE}$ of the mean.

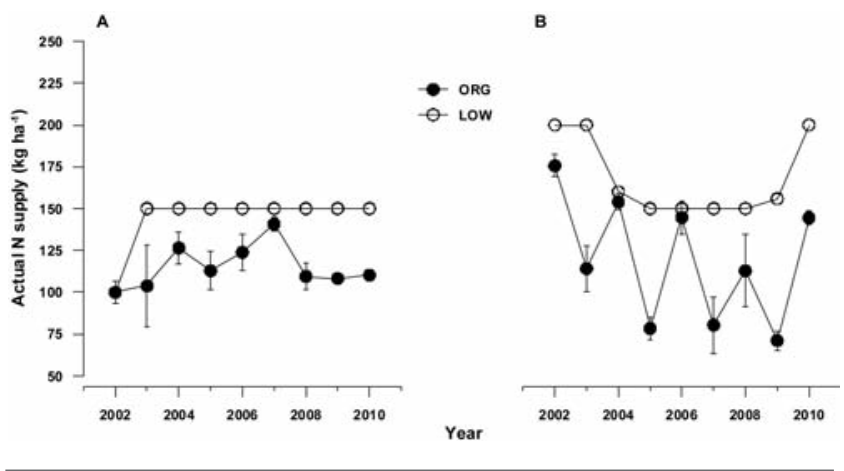

Figure 3. Amount of ex novo $\mathrm{N}\left(\mathrm{kg} \mathrm{ha}^{-1}\right)$ actually supplied to the soil (i.e. green manure legume $\mathrm{Ndfa}$ plus fertilizer $\mathrm{N}$ ) for $\mathrm{A}$ ) maize and $B)$ processing tomato in the organic (ORG=full circles) and the conventional low input (LOW=empty circles) system across years 2002-2010. Vertical bars represent \pm 1 SE of the mean.
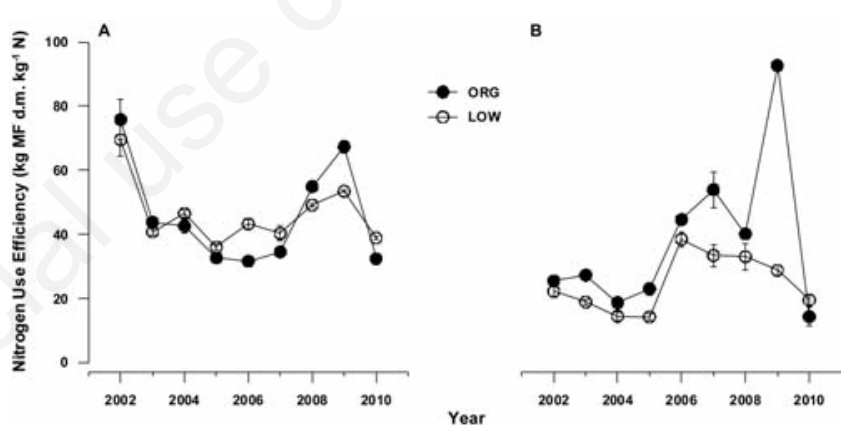

Figure 4. Nitrogen use efficiency (kg of marketable yield dry matter per $\mathrm{kg}$ of $\mathrm{N}$ actually supplied to the soil) for $\mathrm{A}$ ) maize and $\mathrm{B}$ ) processing tomato in the organic ( $\mathrm{ORG}=$ full circles) and the conventional low input (LOW=empty circles) system across years 2002-2010. Vertical bars represent \pm 1 SE of the mean.

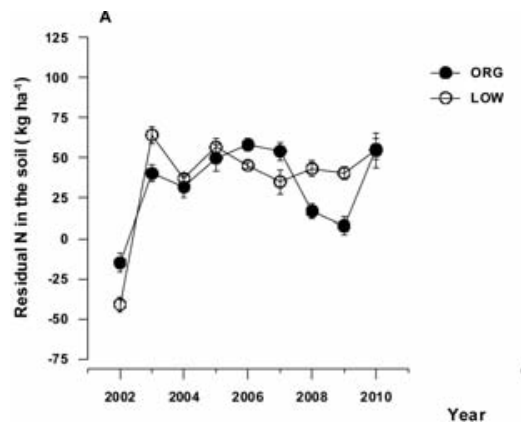

Figure 5. Residual nitrogen in the soil (i.e. green manure legume Ndfa plus fertiliser $\mathbf{N}$ minus $\mathbf{N}$ removed with marketable yield) for $A)$ maize and $B$ ) processing tomato in the organic (ORG=full circles) and the conventional low input (LOW=empty circles) system across years 2002-2010. Vertical bars represent $\pm 1 \mathrm{SE}$ of the mean. 


\section{Discussion}

The inter-annual variability of marketable yield recorded in both systems was mainly due to the effect of season climate during the cash crop cycle, while the lower (maize) and more variable (tomato) marketable yield achieved in the organic system across years (Figure 1) was mainly a consequence of the lower and more variable amount of $\mathrm{N}$ supplied to crops (Figure 3), especially by green manures. Only for tomato marketable yield of 2009 and 2010 variations were clearly due to causes other than $\mathrm{N}$ availability: in 2009 it was conventional tomato that yielded less that potential due to a bad crop establishment; this because a $50 \mathrm{~mm}$ rainfall occurred during seedbed preparation impeding an adequate soil loosening which, on the contrary, could be obtained in the organic soil thanks to green manure biomass incorporated just before; in 2010 the marketable yield loss of organic tomato was due to an unsuccessful mechanical control of weed infestation and to a higher proportion of unmarketable fruits over conventional tomato (36\% vs $20 \%$ of total fruit weight in ORG and LOW, respectively). A lower yield was reported in several studies where maize was grown organically (Mischler et al., 2010; Wortman et al., 2012) or fertilized by cover crops (Tonitto et al., 2006; Teasdale et al., 2008) and was often explained by the lower and variable $\mathrm{N}$ supply from green manures. In turn, the growth and Ndfa accumulation of green manures was affected by fall winter climate and was actually much variable. The green manure Ndfa ranged across years from 33 to $141 \mathrm{~kg} \mathrm{ha}^{-1}$ for maize and from 30 to $132 \mathrm{~kg} \mathrm{ha}^{-1}$ for tomato. Unfortunately, this variability of $\mathrm{N}$ accumulation was not predictable with due accuracy. In fact, parallel field experiments on green manures in the same locality (Benincasa et $a l ., 2008,2010)$ did not allow to find any relationship to explain and predict green manure $\mathrm{N}$ accumulation as a function of season climate. The values of green manure $\mathrm{N}$ supply were generally lower than those reported by Benincasa et al. (2010) and Tosti et al. (2012) for the same location and in some of the years considered in this work. This is due to the fact that those values had been obtained from well cared plot experiments in conventional soils, while our data from the long-term experiment refer to an organic management on a field scale.

It is worth to remember of the fact that our actual $\mathrm{N}$ supply does not take into account root Ndfa (see Materials and methods section) which is known to account for around $5-10 \%$ of total Ndfa (Cazzato et al., 2003). Therefore the actual $\mathrm{N}$ input in the organic system should not have been much different from that used in the conventional low input system where green manure crops were not used. Moreover it should not be disregarded that green manures have also a positive role in preventing leaching of soil mineral $\mathrm{N}$ in rainy fall-winter seasons (Kuo et al., 1997; Tonitto et al., 2006; Salmeron et al., 2010) so contributing to its presence in spring, when it will be returned to the soil with green manure biomass incorporation. The different precession for maize (soft wheat) and tomato (maize) could have partly affected differences between crops in the two systems, although green manure intercrop composition (pure faba bean before maize; barley-vetch mixture before tomato) was expressly conceived to account for expected differences in soil residual $\mathrm{N}$ left by the previous crop and provide different pre-emptive competition and $\mathrm{N}$ supply accordingly (Thorup-Kristensen $e$ t al., 2003).

Also the rate of $\mathrm{N}$ release from green manure biomass and organic fertilizers incorporated into the soil was likely affected by season climate (Quemada, 2004; Justes et al., 2009). This may be crucial for maize, whose $\mathrm{N}$ need during early growth phases is high while current initial $\mathrm{N}$ availability may be low due to both still low soil temperature in early spring and the short time for organic matter mineralization between dates of biomass incorporation and crop establishment (Teasdale et al., 2008). The high clay content of our soil could have fur- ther reduced $\mathrm{N}$ release from green manure biomass (Odhiambo, 2010). Actually, Tosti et al. (2012), found that maize N content after green manures in the same location of our long term trial was sub-optimal as compared to the critical N curve of maize (Plénet and Lemaire, 2000), especially in early growth phases.

The higher amount of biomass incorporated into the soil in the organic system (Figure 2) contributed to the maintenance of a higher long term fertility (Kuo et al., 1997; Berntsen et al., 2006). This may explain the higher nitrogen use efficiency generally observed in organic tomato, including the peak of 2009, when the yield was much high in spite of a very low N supply (Figure 4). The values of nitrogen use efficiency observed in organic tomato are also higher than those observed in previous experiments in the same location for mineral fertilized tomato (Benincasa et al., 2011). The lower N supply for organic tomato has certainly contributed to this result as it is demonstrated that a limited $\mathrm{N}$ availability generally increases both the $\mathrm{N}$ uptake efficiency and the use efficiency of absorbed N (Tei et al., 1999; Benincasa et al., 2011). As far as maize is concerned, the nitrogen use efficiency was similar in both systems and in line with values reported by Teasdale $e t$ al. (2008) for the mineral fertilized crop, but much higher than that reported by these authors for maize sod-seeded on soil covered by surface residues from $\mathrm{N}$ fertilized or non fertilized cover crops. The lower $\mathrm{N}$ supply for both systems in our experiment and for the mineral fertilized crops by Teasdale et al. (2008) may explain this difference and would confirm that the $\mathrm{N}$ rate is the first circumstance affecting the nitrogen use efficiency, more than $\mathrm{N}$ source and the environment (Benincasa et al., 2011).

The lower residual $\mathrm{N}$ (Figure 5) recorded for processing tomato in the organic system demonstrates that tomato took advantage from organic fertilization and that the release of $\mathrm{N}$ from incorporated biomass was in good synchrony with the $\mathrm{N}$ need of this crop. This confirms evidences from Tosti et al. (2012) who found that tomato after green manure vetch was at around the critical $\mathrm{N}$ level (Tei et al., 2002) at any growth stage. On the contrary, in maize the two systems did not differ for residual $\mathrm{N}$. Nonetheless, it is the environmental fate of residual $\mathrm{N}$ that differed between systems in virtue of the crop rotation adopted in our experiment (see Materials and methods section). On one hand the $\mathrm{N}$ left after the harvest of processing tomato, although higher in conventional than in organic system, should not have caused high risks of pollution anyway, because it was likely trapped by winter wheat in both systems. Similarly, the residual N after organic maize was likely trapped by the green manure intercrop (especially by the barley companion). On the other hand, the $\mathrm{N}$ left by conventional maize remained in the bare soil until the establishment of processing tomato in the next spring and in the meanwhile it was exposed to high leaching risk in fall-winter (Gabriel et al., 2012; Salmeron et al., 2010).

\section{Conclusions}

Processing tomato complied with organic cultivation better than maize. As compared to the conventional crop cultivation, organic tomato provided similar yields, used supplied $\mathrm{N}$ more efficiently (on a marketable yield dry matter basis) and left a lower amount of residual $\mathrm{N}$ after harvest, with lower related risks of pollution.

Organic maize yielded less than conventional one. The main limitation for organic maize was represented by the low $\mathrm{N}$ availability during initial growth phases, due to either low $\mathrm{N}$ supply or low rate of $\mathrm{N}$ release from incorporated green manure biomass.

Our experiment confirms that system sustainability for both organic and conventional cultivation depends greatly on the management of soil $\mathrm{N}$ availability and post-harvest residual N. In other words, appropri- 
ate crop rotations are essential in both systems, with cover crops in fallwinter to prevent leaching loss of mineral $\mathrm{N}$ in fall winter. With this regard green manure crops have a strategic role for organic cultivation since they either trap and recycle mineral $\mathrm{N}$ or supply ex novo legume $\mathrm{Ndfa}$ to the soil, with benefits in mitigation of $\mathrm{N}$ pollution and improvement of self-sufficiency of the system.

\section{References}

Benincasa P, Tei F, Guiducci M, 2011. The nitrogen use efficiency: meaning and sources of variation - case studies on three vegetable crops in Central Italy. Hort. Technol. 21:266-73.

Benincasa P, Tosti G, Boldrini A, Tei F, Guiducci M, 2008. Poliennal results on soil $\mathrm{N}$ management and maize $\mathrm{N}$ nutrition by green manuring. pp 194-198 in Proc. 2nd Scientific Conf. ISOFAR, Modena, Italy.

Benincasa P, Tosti G, Tei F, Guiducci M, 2010. Actual N availability from winter catch crops used for green manuring in maize cultivation. J. Sust. Agric. 34:705-23.

Berntsen J, Olesen J, Petersen B, Hansen E, 2006. Long-term fate of nitrogen uptake in catch crops. Eur. J. Agron. 25:383-90.

Boldrini A, Benincasa P, Gigliotti G, Businelli D, Guiducci M, 2008. Effects of an organic and a conventional cropping system on soil fertility. pp 324-327 in Proc. 2nd Scientific Conf. ISOFAR, Modena, Italy.

Boldrini A, Benincasa P, Tosti G, Tei F, Guiducci M, 2007. Apparent N balance in organic and conventional low input cropping system. pp 264-267 in Proc. 3rd Int. QLIF Congr., Hohenheim, Germany.

Cazzato E, Venticelli P, Corleto A, 2003. N2 fixation of annual fodder legumes in Mediterranean environment. Note 2. Comparison between difference and isotope dilution methods and evaluation of two grass species as reference crops. Rivista di Agronomia 37:63-8.

de Ponti T, Rijk B, van Ittersum MK, 2012. The crop yield gap between organic and conventional agriculture. Agric. Syst. 108:1-9.

Farneselli M, Tosti G, Benincasa P, Guiducci M, Tei F, 2009. Potential N leaching under several fertilisation strategies in processing tomato. pp 145-146 in Proc. 16th N Workshop: Connecting different scales of Nitrogen use in agriculture, Turin, Italy.

Ferron P, Deguine JP, 2005. Crop protection, biological control, habitat management and integrated farming. A review. Agron. Sustain. Dev. 25:17-24.

Fließbach A, Oberholzer HR, Gunst L, Mäder P, 2006. Soil organic matter and biological soil quality indicators after 21 years of organic and conventional farming. Agric. Ecosys. Environ. 118:273-84.

Gabriel JL, Munoz-Carpena R, Quemada M, 2012. The role of cover crops in irrigated systems: Water balance, nitrate leaching and soil mineral nitrogen accumulation. Agric. Ecosyst. Environ. 155:50-61.

Graziani F, Onofri A, Pannacci E, Tei F, Guiducci M, 2012. Size and composition of weed seedbank in long-term organic and conventional low-input cropping systems. Eur. J. Agron. 39:52-61.

Justes E, Mary B, Nicolardot B, 2009. Quantifying and modelling C and
$\mathrm{N}$ mineralization kinetics of catch crop residues in soil: parameterization of the residue decomposition module of STICS model for mature and non mature residues. Plant Soil 325:171-85.

Kuo S, Sainju UM, Jellum EJ, 1997. Winter cover cropping influence on nitrogen in soil. Soil Sci. Soc. Am. J. 61:1392-9.

Mischler T, Duiker SW, Curran WS, Wilson D, 2010. Hairy vetch management for no till organic corn production. Agron. J. 102:355-62.

Odhiambo JJ0, 2010. Decomposition and nitrogen release by green manure legume residues in different soil types. Afr. J. Agric. Res. 5:90-6.

Plénet D, Lemaire G, 2000. Relationship between dynamics of nitrogen uptake and dry matter accumulation in maize crops. Determination of critical N concentration. Plant Soil 216:65-82.

Quemada M, 2004. Predicting crop residue decomposition using moisture adjusted time scales. Nutr. Cycl. Agroecosyst. 70:283-91.

Salmeron M, Cavero J, Quilez D, Isla R, 2010. Winter cover crops affect monoculture maize yield and nitrogen leaching under irrigated Mediterranean conditions. Agron. J. 102:1700-9.

Teasdale JR, Abdul-Baki AA, Park YB, 2008. Sweet corn production and efficiency of nitrogen use in high cover crop residue. Agron. Sust. Dev. 28:559-65.

Tei F, Benincasa P, Guiducci M, 1999. Nitrogen fertilisation on lettuce, processing tomato and sweet pepper: Yield, nitrogen uptake and the risk of nitrate leaching. Acta Hort. 506:61-7.

Tei F, Benincasa P, Guiducci M, 2002. Critical nitrogen concentration in processing tomato. Eur. J. Agron. 18:45-55.

Thorup-Kristensen K, Dresboll DB, Kristensen HL, 2012. Crop yield, root growth, and nutrient dynamics in a conventional and three organic cropping systems with different levels of external inputs and $\mathrm{N}$ re-cycling through fertility building crops. Eur. J. Agron. 37:66-82.

Thorup-Kristensen K, Magid J, Jensen LS, 2003. Catch crops and green manures as biological tools in nitrogen management in temperate zones. Adv. Agron. 79:227-302.

Thorup-Kristensen K, Dresbøll DB, 2010. Incorporation time of nitrogen catch crops influences the $\mathrm{N}$ effect for the succeeding crop. Soil Use Manage. 26:27-35.

Tonitto C, David MB, Drinkwater LE, 2006. Replacing bare fallows with cover crops in fertilizer-intensive cropping systems: A meta-analysis of crop yield and N dynamics. Agric. Ecosyst. Environ. 112:58-72.

Tosti G, Benincasa P, Farneselli M, Pace R, Tei F, Guiducci M, ThorupKristensen K, 2012. Green manuring effect of pure and mixed barley - hairy vetch winter cover crops on maize and processing tomato N nutrition. Eur. J. Agron. 43:136-46.

Tosti G, Boldrini A, Benincasa P, Tei F, Guiducci M, 2008. The N nutritional status of processing tomato grown after green manures. Ital. J. Agr. 3:275-6.

Watson CA, Atkinson D, Gosling P, Jackson LR, Rayns FW, 2002. Managing soil fertility in organic farming systems. Soil Use Manage. 18:239-47.

Wortman SE, Galusha TD, Mason SC, Francis CA, 2012. Soil fertility and crop yields in long-term organic and conventional cropping systems in Eastern Nebraska. Renew. Agr. Food Syst. 27:200-16. 